\title{
Reforming Rowbotham: Towards Fairer Financial Eligibility Standards for State-Funded Counsel in Criminal Trials
}

\section{Manasvin Goswami (Veenu)*}

\author{
"Inaccessible justice costs us all, but visits its \\ harshest consequences on the poorest people in \\ our communities."1 \\ "It should be obvious to any outside observer that \\ the income thresholds being used by Legal Aid \\ Ontario do not bear any reasonable relationship \\ to what constitutes poverty in this country."
}

Every year, thousands of Canadians contest criminal charges without legal representation. ${ }^{3}$ Some of these accused may appear pro se on a voluntary basis. Others - and in all likelihood, the vast majority - self-represent due to exigent financial circumstances. ${ }^{4}$ An increasing number of criminal defendants are being forced into the latter category courtesy of strict, outdated Legal Aid eligibility criteria. ${ }^{5}$ To safeguard those defendants' rights under sections 7 and 11(d) of the Charter, Canadian courts will, in certain circumstances, stay criminal proceedings against them until they are provided with state-funded counsel. This remedy, most notably recognized by the Ontario Court of Appeal in $R v$. Rowbotham and affirmed in several subsequent judgments, is triggered when an accused person shows that:

(1) representation by counsel is essential to a fair trial (the "Fairness Branch"); and

(2) they lack the means to pay for counsel (the "Financial Branch"). ${ }^{6}$

This paper argues for a more expansive interpretation of the Financial Branch. While
Rowbotham applications are a vital complement to Legal Aid, a pervasive line of jurisprudence is unduly restricting their scope by limiting their availability to situations of "exceptional" financial need. This approach should be abandoned. It downplays the importance of the right to a fair trial and is insensitive to this country's welldocumented crisis of access to justice. ${ }^{7}$ Instead, courts should:

(a) clarify that Rowbotham orders are not restricted to situations of exceptional financial need; and

(b) re-focus the Financial Branch on assessing whether an accused has made all "reasonable efforts" to obtain representation.

My argument proceeds in three parts. First, I provide background on Rowbotham orders and the circumstances in which they are granted. I then critique one prevailing approach to interpreting the Financial Branch before outlining and justifying my proposed changes to that approach. Finally, I address possible objections to my position.

\section{A. Rowbotham Applications: The Status Quo}

The Charter does not guarantee criminal defendants access to state-funded counsel. ${ }^{8}$ However, 
Canadian courts have recognised that, in certain circumstances, the Crown is obliged to provide accused persons with legal representation to uphold their rights under sections 7 and 11(d) of the Charter. In $R v$. Rowbotham, the Ontario Court of Appeal specified the circumstances in which such an obligation arises in criminal trials, as follows:

\begin{abstract}
However, in cases not falling within provincial legal aid plans, ss. 7 and $11(d)$ of the Charter, which guarantee an accused a fair trial in accordance with the principles of fundamental justice, require funded counsel to be provided if the accused wishes counsel but cannot pay a lawyer, and representation of the accused by counsel is essential to a fair trial. ${ }^{9}$
\end{abstract}

Accordingly, defendants applying to a court for state-funded counsel in criminal trials must show that:

(1) their case does not fall within a provincial legal aid plan;

(2) representation by counsel is essential to a fair trial (the "Fairness Branch"); and

(3) they lack the means to pay for counsel (the "Financial Branch").

In adjudicating the Fairness Branch, courts typically consider the seriousness of the charges the accused faces, the anticipated length and complexity of the proceedings and the accused's ability to participate effectively and defend the case. ${ }^{10}$ However, a finding that representation by counsel is essential to a fair trial is not dispositive of a Rowbotham application. Accused persons must also demonstrate that they "lack the means" to pay for counsel.

\section{(i) The Financial Branch: Divergent Approaches}

Rowbotham provides little guidance on determining whether an accused "lacks the means" to secure legal representation. As a result, subsequent judgments have interpreted the Financial Branch in an inconsistent fashion. Two general approaches have materialised. As I argue below, one should be abandoned.
The first approach limits the availability of Rowbotham applications to situations of "exceptional" or "extraordinary" financial need (the "Exceptional Need" approach). Most frequently attributed to the British Columbia Supreme Court's decision in $R v$. Malik, ${ }^{11}$ the Exceptional Need approach is notionally rooted in the following excerpt from Rowbotham:

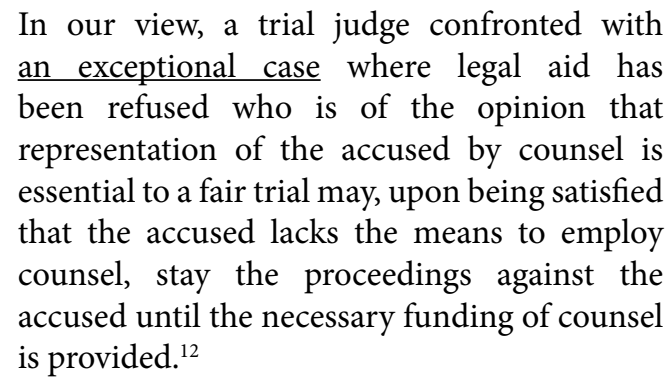

The Exceptional Need Approach has been followed in a number of judgments across the country, including the British Columbia Supreme Court's decisions in Reinbrecht ${ }^{13}$ and Mostowy, ${ }^{14}$ the Ontario Superior Court's decisions in Rowe, ${ }^{15}$ Tennina, ${ }^{16}$ and Ighedoise,${ }^{17}$ the Alberta Court of Queen's Bench's ruling in Sup, ${ }^{18}$ and the British Columbia Court of Appeal's decision in Crichton, ${ }^{19}$ among others. ${ }^{20}$

A second line of cases makes no reference to "extraordinary" or "exceptional" financial need as a pre-requisite for a successful Rowbotham application. Instead, these cases focus on whether applicants have made "reasonable sacrifices" and/or "reasonable efforts" to pay for counsel (the "Reasonable Effort" approach). Judgments following this approach include the Ontario Court of Appeal's decision in Rushlow ${ }^{21}$ the Ontario Superior Court's decisions in Woods, ${ }^{22}$ Davidson, ${ }^{23}$ and Giroux ${ }^{24}$ the British Columbia Supreme Court's decision in $\mathrm{Kim}^{25}$ and the Manitoba Court of Appeal's decision in $R$ v. Drury. ${ }^{26}$

In Catholic Children's Aid Society of Ontario, Justice Murray described the divergence between the Exceptional Need and Reasonable Effort approaches as follows:

There is no precise definition of indigence contained in the jurisprudence on the right to state-funded counsel in protection 
proceedings. Some courts adopt a rigorous standard, reflecting their understanding of the test set out in Rowbotham applications in criminal cases, as developed further in the B.C case R. v. Malik ... . It is worth not[ing] that the Ontario Court of Appeal in a recent criminal case, $R$. $v$. Rushlow, set out a less restrictive approach to a financial test for the appointment of state-funded counsel than that found in R.v. Malik ... . When compared to the Malik approach, the approach found in Rushlow is more focussed on an applicant's present circumstances, and slower to deny an application based on a lack of prudence in managing one's financial affairs from the beginning of the case, unless it is shown that an applicant has deliberately depleted assets in order to avoid paying for a lawyer. ${ }^{27}$

The Exceptional Need and Reasonable Effort approaches diverge on a number of issues related to Rowbotham applications. For instance, while Canadian courts broadly agree that Rowbotham applicants must tender evidence detailing their financial circumstances, judges following the Exceptional Need approach generally impose stricter financial disclosure requirements. ${ }^{28}$ The Exceptional Need approach also demands more onerous sacrifices from applicants to secure representation and is less forgiving of an applicant's failure to prioritize funding for counsel over almost all other expenses. ${ }^{29}$ Finally, judges adopting the Exceptional Need approach often refer to the "high" burden on applicants in Rowbotham proceedings. ${ }^{30}$ By contrast, judges employing the Reasonable Effort standard tend to emphasize that applicants need only establish inability to pay on a balance of probabilities. ${ }^{31}$

\section{(ii) The Problems With the Exceptional Need Approach}

The Exceptional Need approach accords insufficient weight to the core value animating Rowbotham orders: trial fairness. It is also premised upon an incorrect interpretation of Rowbotham itself. For both these reasons, it should be abandoned in favour of the Reasonable Effort standard.

\section{(a) Insufficient Weight to Trial Fairness}

The Exceptional Need approach endangers trial fairness by elevating financial eligibility to a factor of disproportionate significance. Rowbotham orders are granted for one purpose: to preserve the fairness of an accused's trial. ${ }^{32}$ This rationale animates the Fairness Branch. The Financial Branch has a distinct function. As recognized in Rowbotham itself, the Financial Branch exists because:

\section{As a matter of common sense, an accused who is able to pay the costs of his or her defence is not entitled to take the position that he or she will not use personal funds but still to require legal aid to bear the cost of his or her defence. $\underline{A}$ person who has the means to pay the costs of his or her defence but refuses to retain counsel may properly be considered to have chosen to defend himself or herself. ${ }^{33}$}

This passage clarifies that the Financial Branch exists to screen out individuals who have "chosen to defend" themselves, and are therefore disentitled to state funding. While this function is undoubtedly important, it should not overwhelm the more fundamental purpose of preserving trial fairness. Yet, the Exceptional Need approach creates precisely that risk, for three reasons.

First, defendants who are not in circumstances of "exceptional financial need" may not have "chosen to defend" themselves in any meaningful sense. These defendants may be unwilling - quite reasonably - to deplete their savings and endanger their livelihood and their family's well-being to secure counsel for trial. This choice should not diminish their interest in a fair trial. The significant socio-economic barriers constraining these individuals' interactions with the justice system have been extensively canvassed in legal and sociological scholarship. ${ }^{34}$ The Exceptional Need approach ignores these valuable lessons and unduly prioritizes a defendant's "choice" to self-represent over the fairness of that defendant's trial. ${ }^{35}$

Second, the degree of financial disclosure required under the Exceptional Need approach may exacerbate access to justice concerns and, 
by extension, compromise trial fairness. As Justice Skilnick noted in British Columbia (Director of Child, Family \& Community Service) v. L (T.), extensive disclosure requirements may simply "add more obstacles for those most in need of assistance." ${ }^{36}$

Finally, the Exceptional Need approach ignores society's interest in a fair trial process. A substantively or procedurally deficient trial is not simply an affront to an individual's Charter rights: it also weakens the perception of the justice system as a fair and equally accessible institution. ${ }^{37}$ The Exceptional Need approach focuses solely on the individual defendant and is therefore unable to account for the significant social interest in having a trial process that is beyond reproach.

\section{(b) Incorrect Interpretation of Rowbotham}

The Exceptional Need approach is premised upon a flawed interpretation of $R v$. Rowbotham. As Justice Rosenberg aptly noted in Rushlow,

\footnotetext{
Because of the pervasiveness of legal aid, it will be the rare and exceptional case that the court will find it necessary to appoint counsel. This does not mean that counsel is only required in exceptional cases. Rather, it is the fact that legal aid is available for accused who cannot afford a lawyer that Rowbotham orders are exceptional. ${ }^{38}$
}

While Justice Rosenberg's comments addressed the Fairness Branch, his observations apply with equal force to the Financial Branch. Judicial interpretation of both the Fairness and Financial branches has been influenced by the assumption that Rowbotham orders are an "exceptional" remedy. However, as Justice Rosenberg notes, this assumption is not a normative claim about Rowbotham orders themselves, but a descriptive point about how frequently they will be required. It is premised upon a view of Legal Aid that flies in the face of the significant budgetary challenges the program faces in most provinces. ${ }^{39}$ The Alberta Court of Queen's Bench and British Columbia Provincial Court have both recognized this discrepancy, but have been bound by appellate jurisprudence favouring the Exceptional Need approach. ${ }^{40}$ That jurispru- dence should be overruled. In the same way that the Court of Appeal for Ontario clarified that an "exceptional" standard was inappropriate for the Fairness Branch, appellate courts across the country should affirm that the Financial Branch should not be governed by the Exceptional Need standard.

\section{B. The Way Forward}

Rowbotham applications require a culture shift. The Supreme Court of Canada's decision in Hyrniak v. Mauldin ${ }^{41}$ provides useful guidance for the conceptual approach I envision. ${ }^{42}$ In that case, Justice Karakatsanis noted that lower courts had been placing too much emphasis on the "full appreciation" of evidence that can be gained at a conventional trial, given that such a trial is not a realistic alternative for most litigants." 43 She proposed a "culture shift" with respect to summary judgment. ${ }^{44}$ Similarly, appellate courts should initiate a culture shift around Rowbotham applications. They should definitively state that some judges have been placing undue emphasis on the Financial Branch by adopting overly stringent standards that are insensitive to Canada's access to justice crisis and that detract from the core purpose of Rowbotham orders: ensuring trial fairness.

Rejecting the Exceptional Need approach will not entail de novo development of an alternate standard; the current Reasonable Effort approach provides a suitable alternative. Nonetheless, for greater clarity, I support the following interpretation of the Financial Branch:

- Applicants need not demonstrate "exceptional financial need" to satisfy the Financial Branch. The primary purpose of the Financial Branch is to screen out applicants who have "chosen to defend themselves." Courts should conduct this inquiry by assessing whether a defendant has made all "reasonable efforts" to secure representation. This analysis should be informed by the applicant's income, assets, and whether the applicant has made reasonable sacrifices and arranged her finances in a manner that reasonably prioritized her legal defense. 
- Financial disclosure requirements and definitions of "reasonable efforts/sacrifices" should display sensitivity to systemic barriers that hinder effective interaction with the justice system. Examples of these barriers include specific difficulties some accused persons face in navigating the trial process flowing from their income and literacy level, spoken language and disabilities (physical and mental), as well as a more general lack of trust and confidence in the justice system among marginalized groups that have historically experienced discrimination in their interactions with the criminal justice system and broader Canadian society. ${ }^{45}$ These barriers hamper effective access to justice and can discourage accused persons from devoting a substantial portion of their income towards funding counsel. Courts should be attentive to these factors when interpreting terms such as "reasonable" sacrifice and "reasonable" financial disclosure.

- Applicants must satisfy each element of the Rowbotham test on a balance of probabilities. There is no "higher" burden with respect to the Financial Branch or any other stage of the Rowbotham test. Financial disclosure from applicants is required to the extent that it establishes incapacity to fund counsel on a balance of probabilities.

\section{Objections}

Two objections may be levied against my proposal. First, my approach may inject significant uncertainty into Rowbotham jurisprudence. Concepts like "reasonable effort" and "reasonable sacrifice" do not always lend themselves to clear, consistent application by courts. Second, a less stringent Financial Branch may be insufficiently deferential to provincial legislatures. It may force courts to grapple with questions of resource distribution and social spending that are outside of their institutional competence and appropriate constitutional role. While both objections have merit, neither undermines my argument.
The first objection regarding uncertainty suffers from three flaws. First, there is significant uncertainty around the Financial Branch at present given the two contrasting approaches identified earlier. Definitively overruling the Exceptional Need approach will, in fact, introduce greater certainty into the status quo. Such a development will also bolster the rule of law by ensuring that Rowbotham orders are less contingent upon the interpretive preferences of individual judges. Second, courts have successfully adjudicated applications for state-funded counsel in child custody proceedings without an "exceptional financial need" standard. In New Brunswick v. G(J.), the Supreme Court of Canada saw no need to limit eligibility for such applications to defendants in exceptional financial circumstances. ${ }^{46}$ While Justice Lamer limited his remarks in New Brunswick to the child protection context, his approach serves as a useful reminder that courts can effectively apply financial eligibility standards without an "exceptional circumstances" rule. Third, "exceptional financial need" is not an intrinsically clearer concept than "all reasonable efforts" - it simply serves as a clearer signaling mechanism to judges that Rowbotham applications should be granted in rare circumstances. "Clarity" of this sort is hardly valuable if it comes at the expense of trial fairness. Any marginal increase in uncertainty caused by a shift away from the Exceptional Need standard is well worth the improvements in access to justice and trial fairness that will accompany a less stringent approach to the Financial Branch.

The objection regarding institutional competence carries greater weight, but is ultimately unpersuasive. Courts have repeatedly affirmed that Rowbotham applications should be adjudicated without concern for how a particular decision will impact the operations of Legal Aid. ${ }^{47}$ This is because Rowbotham orders fall squarely within a provincial/superior court's constitutional prerogative to uphold trial fairness. ${ }^{48}$ While a less stringent Financial Branch might impact resource distribution, any such consequences flow from robust protection of Charter rights, a task firmly within the institutional competence of the courts. ${ }^{49}$ 
The Supreme Court of Canada adopted a similar approach when addressing access to state-funded duty counsel programs in $R v$. Prosper..$^{50}$ The Court's introduction of a "holdingoff" period under section 10(b) made it harder to prosecute offences involving breathalyzer evidence in jurisdictions without access to free 24-hour duty counsel. In effect, the Court presented provincial governments with a choice: enact more extensive duty counsel schemes or risk losing access to potential convictions flowing from favorable evidentiary presumptions under the Criminal Code. ${ }^{51}$ The fact that this choice involved potential expenditure of government funds did not deter the Supreme Court from asserting its central role in safeguarding Charter rights. A similar approach is justified in the context of Rowbotham orders. The pursuit of a constitutionally-compliant conviction often requires expenditure of public funds. That fact alone should not influence the standards governing the Financial Branch. Charter protections are often most crucial for those groups who lack political capital to secure access to public funds; in fact, Rowbotham applications arose precisely because Legal Aid programs were not covering unrepresented criminal defendants who were unable, by any reasonable measure, to cover the cost of their own defense. By according significant deference to unrealistic Legal Aid criteria, the Exceptional Need approach entrenches the very problems that animated Rowbotham orders in the first place.

In any event, fears that my approach will significantly impact government spending ability are likely overstated. A less stringent Financial Branch will not open the floodgates to successful Rowbotham applications. Applicants will still need to satisfy the Fairness Branch and the various requirements it imposes. ${ }^{52}$ Moreover, the Reasonable Effort standard can serve as a meaningful check against unwarranted expenditure of public funds, as evidenced by the decisions following that approach that have nonetheless rejected Rowbotham applications. ${ }^{53}$

\section{Conclusion}

Rowbotham orders uphold the Charter's promise of trial fairness for individuals who are ineligible for Legal Aid, but unable to afford counsel. However, some courts are weakening that promise by interpreting the Financial Branch in an overly stringent fashion. They are limiting Rowbotham orders to individuals in "exceptional" financial circumstances, requiring those individuals to provide copious financial disclosure, and punishing them when they fail to prioritize their defense above and beyond almost all other expenses in their lives. This approach undermines trial fairness, misinterprets $R v$. Rowbotham, and ignores systemic barriers that many defendants face in their interactions with the justice system. The Exceptional Need approach should be abandoned. Instead, the Financial Branch should be interpreted and applied with greater sensitivity to the socio-economic obstacles confronting the individuals who most require the justice system's assistance.

\section{Endnotes}

* Juris Doctor Candidate 2017, University of Toronto.

1 The Canadian Bar Association, "Reaching Equal Justice Report: An Invitation to Envision and Act" (Report of the CBA Access to Justice Committee, November 2013) at 8 [Reaching Equal Justice].

$2 R v$ Moodie, 2016 ONSC 3469 at para 6, [2016] OJ No 2727 [Moodie].

3 Robert J Hann \& Joan Nuffield, Court Site Study of Adult Unrepresented Accused in the Provincial Criminal Courts - Part 1: Overview Report (Ottawa: Research and Statistics Division, Department of Justice Canada, 2002) at 6, 14.

4 Julie Macfarlane, The National Self-Represented Litigants Project: Identifying and Meeting the Needs of Self-Represented Litigants (Treasurer's Advisory Group on Access to Justice, 2013) at 39. Dr. Macfarlane's study indicated that, in the family and civil context, "by far, the most consistently cited reason for self-representation was the inability to afford to retain, or continue to retain, legal counsel." I anticipate the same observation holds true in the criminal context. 
5 Jennifer Bond, "Failure to Fund: The Link between Canada's Legal Aid Crisis \& Unconstitutional Delay in the Provision of State-Funded Legal Counsel" (2015) 35:1 NJCL 1 at 8; Reaching Equal Justice, supra note 1 at $42-44$.

$6 R v$ Rowbotham, [1988] 41 CCC (3d) 1 at 66, 25 OAC 321 [Rowbotham].

7 See infra note 34.

8 Christie $v$ British Columbia (Attorney General)v, 2007 SCC 21 at para 25, [2007] 1 SCR 873.

9 Rowbotham, supra note 6 at 66 (emphasis added in bold, italics in original). Rowbotham remains the leading Canadian authority on applications for state-funded counsel in criminal trials (so much so that these applications are commonly referred to as Rowbotham applications). Rowbotham applications have been increasing at an "exponential" rate over the last twenty years: see Bond, supra note 5 at 9.

$10 R v$ Rushlow, 2009 ONCA 461 at para 19, 245 CCC (3d) 505 [Rushlow].

$11 R v$ Malik, 2003 BCSC 1439, [2003] BCJ No 2167 [Malik].

12 Rowbotham, supra note 6 at 69 (emphasis added).

$13 R v$ Reinbrecht, 2016 BCSC 1790 at paras 66, 70, [2016] BCJ No 2038 [Reinbrecht].

$14 R v$ Mostowy, 2014 BCSC 2479 at paras 25, 53, [2014] BCJ No 3484 [Mostowy].

$15 R v$ Rowe, 2016 ONSC 6144 at para 12, [2016] OJ No 5062.

$16 R v$ Tennina, 2010 ONSC 6246 (Div Ct) at paras 42-43, 47, 53, [2010] OJ No 6219.

$17 R v$ Idghedoise, 2016 ONSC 5623 at para 11, [2016] OJ No 4730.

$18 R v$ Sup, $2016 \mathrm{ABQB} 110$ at para 21, [2015] AJ No 1465 [Sup].

$19 R v$ Crichton, 2015 BCCA 138 at para 49, 319 CCC (3d) 504 [Crichton].

20 See also $R v$ Black Pine Enterprises Ltd, 2001 BCSC 1849 at para 4, [2001] BCJ No 2926 [Black Pine Enterprises]; $R$ v Austria, 2012 MBQB 298 at para 15, 285 Man R (2d) 203; $R v$ Edrissi, 2013 BCSC 1287 at para 19, [2013] BCJ No 1562 [Edrissi].

21 Rushlow, supra note 10 at paras 29-30 (the Court of Appeal found that the Financial Branch had been satisfied even though "[p]erhaps the appellant could have made further efforts to privately retain counsel and he may have made some poor financial decisions.")

$22 R v$ Woods, 2016 ONSC 2374 at para 15, [2016] OJ No 1794 [Woods].

$23 R v$ Davidson, 2015 ONSC 2655 at paras 19-20, [2015] OJ No 2041 [Davidson].
$24 R v$ Giroux, 2006 CarswellOnt 5573 (Ont Sup Ct) at para 42, [2006] OJ No 5836 [Giroux].

$25 R v$ Kim, 2011 BCSC 137 at para 53, [2011] BCJ No $162[$ Kim $]$.

$26 R v$ Drury, 2000 MBCA 100 at para 65, [2001] 1 WWR 442 [Drury]. See also: $R v$ Oduh, 2016 ONSC 6370 at para 7, [2016] OJ No 5338 [Oduh].

27 Catholic Children's Aid Society of Ontario v C (JR), 2015 ONCJ 729 at paras 81-82, 89, 73 RFL (7th) 431 (emphasis added).

28 See for example: Edrissi, supra note 20 at paras 7-9, 19; Reinbrecht, supra note 13 at para 70; Mostowy, supra note 14 at paras. 64, 69; Black Pine Enterprises, supra note 20 at paras 3-4.

29 See for example: Crichton, supra note 19 at paras 52-53; Rowe, supra note 15 at paras 36-38; $R v$ Alcock, 2007 BCSC 1452, cited in Mostowy, supra note 14 at para 60.

30 See for example: Malik, supra note 11 at para 22; Crichton, supra note 19 at para 40; Sup, supra note 18 at para 21; Reinbrecht, supra note 13 at para 66; $R v$ Cai, 2002 ABCA 299 at para 6, 170 CCC (3d) 1.

31 Giroux, supra note 24 at para 42; Davidson, supra note 23 at para 26; Kim, supra note 25 at para 53; $R v$ Baksh, 2013 ONCJ 57 at para 13, [2013] OJ No 671; $R v$ Eid, 2013 ONSC 7084 at paras 8, 11, [2013] OJ No 5184; $R v$ Conklin, 2012 ONSC 5259 at paras 20,26, 28, 37, [2012] OJ No 4404; $R v$ Sheikh, 2011 ONSC 4942 at paras 7, 71-72, [2011] OJ No 4435.

32 Drury, supra note 26 at para 23; $R v$ Ryan, 2012 NLCA 9 at para 94, 281 CCC (3d) 352 [Ryan]; Rowbotham, supra note 6 at 66,$70 ; R v$ Peterman (2004), 185 CCC (3d) 352 at 360, 70 OR (3d) 481 [Peterman]; $R v$ Druken, 2003 NLSCTD 150 at paras 26-28, [2000] NJ No 249.

33 Rowbotham, supra note 6 at 64 (emphasis added).

34 See for example: Reaching Equal Justice, supra note 1; Trevor CW Farrow, "What is Access To Justice?" (2014) 51:3 Osgoode Hall LJ 957; Mary Jane Mossman \& Patricia Hughes, Re-Thinking Access to Criminal Justice in Canada: A Critical Review of Needs, Responses and Restorative Justice Initiatives (Ottawa: Research and Statistics Division, Department of Justice Canada, 2001); Albert Currie, Riding the Third Wave: Rethinking Criminal Aid Within An Access to Justice Framework (Ottawa: Research and Statistics Division, Department of Justice Canada, 2004); Andrew I Nathanson, "Rowbotham Applications: Levelling the Playing Field" (Paper delivered at the Advocate's Club, Vancouver, 17 November 2003) at 7-8; Roderick A Macdonald, "Access to Justice in Canada Today: Scope, Scale and Ambitions" 
in Julia Bass, WA Bogart \& Frederick H Zemans, eds, Access to Justice for a New Century - The Way Forward (Toronto: Law Society of Upper Canada, 2005); Michael Trebilcock, Anthony Duggan \& Lorne Sossin, eds, Middle Income Access to Justice (Toronto: University of Toronto Press, 2012).

35 This is not to say that an expanded approach to Rowbotham applications is a panacea for Canada's access to justice crisis. "Access to justice" is a broader concept than "access to legal representation." Albert Currie explains that access to justice has been framed in Canada through three "waves." Individualized access to legal representation is part of the "first wave," and has been supplemented by a more holistic focus on collective litigation strategies, spreading public information about the justice system, promoting diversion programs, tackling poverty at its root etc. However, Currie acknowledges that "[e]ven as a first wave access to justice movement, criminal legal aid is very much an unfinished project." A shift away from the "Extraordinary Need" approach would display sensitivity to continued struggles to solve first wave access to justice issues: Currie, supra note 34 at 3-6.

36 British Columbia (Director of Child, Family \& Community Service) $v$ L (T), 2009 BCPC 293 at para 16, 73 RFL (6th) 455.

37 Rushlow, supra note 10 at para 39; Ryan, supra note 32 at paras 94-97, 151; $R v$ Dew, 2009 MBCA 101 at paras 80, 88-89, 95, 247 CCC (3d) 487 [Dew]; $R v$ Smart, 2014 ABPC 175 at para 108, [2014] 11 WWR 757.

38 Rushlow, supra note 10 at para 19.

39 Reaching Equal Justice, supra note 1 at 37-41; Moodie, supra note 2 at para 6.

40 See $R$ v I (VC), 2014 ABQB 684 at paras 28-33, 2014 CarswellAlta 2737; $R v$ Williams, 2010 BCPC 16 at paras 176-179, 2010 CarswellBC 323.
412014 SCC 7, [2014] 1 SCR 87 [Hyrniak].

42 Though not the substantive changes I propose.

43 Hyrniak, supra note 41 at para 4.

44 Ibid at paras 2, 32.

45 Reaching Equal Justice, supra note 1 at 17-22.

46 New Brunswick (Minister of Health and Community Services) $v$ G (J), [1999] 3 SCR 46, 177 DLR (4th) 124. Justice Adair makes this point at paras 5862 of his reasons in British Columbia (Director of Child, Family \& Community Service) v L (T), 2010 BCSC 105, 80 RFL (6th) 22.

47 Rushlow, supra note 10 at paras 18, 25; Peterman, supra note 32 at $361 ; R v$ Serre, 2010 ONSC 714 at para 10, 2010 CarswellOnt 518; Oduh, supra note 26 at para 7.

48 Peterman, supra note 32 at 361 ; Dew, supra note 37 at para 23; Rowbotham, supra note 6 at 69.

49 Ibid. Micah B Rankin provides separate justification for this conclusion in "Access to Justice and the Institutional Limits of Independent Courts" (2012) 30:1 Windsor YB Access Just 101. Rankin bases his argument on an expanded conception of judicial independence.

$50 R v$ Prosper, [1994] 3 SCR 236, 118 DLR (4th) 154.

51 Ibid at 275-276.

52 Due to space constraints, I do not engage in depth with another possible objection: that Rowbotham applicants should bear a heavy burden of proof because they are alleging a potential Charter breach. Justice McArthur provides persuasive responses to this objection in Baksh (supra note 31 at paras 7-13).

53 See Woods, supra note 22; Giroux, supra note 24; Drury, supra note 26. 